\title{
Creating Characteristic Training Platform to Deal with Opportunity and Challenge in Low-carbon Economy
}

\author{
Xingjia Liu \\ Harbin University of Science and Technology, Harbin, China \\ xj3333333@sina.com
}

\begin{abstract}
Keywords: Professional training objectives; Special training platform; Improving competitiveness; Energy majors; Low-carbon
\end{abstract}

\begin{abstract}
The purpose of this paper is to study the establishment of talent training platform in which low-carbon talents can be trained, in order to meet the talent market demand. This paper analyzes the necessity of producing low-carbon economy and the urgency of cultivating low-carbon talents as well as the high demand and diversity of talent demand, from the perspective of low-carbon talent cultivation strategy; analyzes the opportunities and challenges of the energy majors in low-carbon talent training. The results show that the talent cultivating target of wide caliber is extremely important to meet the needs for low-carbon talent cultivation. In view of the above, our personnel training objectives in our energy majors are established and the requirements of the knowledge and ability to support the talent training objectives are proposed. The talent training goals can meet the demand of low-carbon talent market, can reflect the advantages of our school, and can help us to build the professional talent training platform and to effectively combat the opportunities and challenges in the low-carbon talent training.
\end{abstract}

\section{Introduction}

The global problem such as energy shortage and environmental change is an inevitable problem in the process of economic development. With the accelerated pace of economic development, how to better solve the effective use of energy and the protection of the environment is imminent. To realize the change from the traditional economic growth model to the low-carbon economic growth model is the inevitable choice to solve these problems.

However, this transformation has a long way to go, needs high level technical talents. Colleges and universities are an important base for personnel training, training low-carbon talent is duty-bound. And as a energy majors which has a very close relationship with low-carbon should more shoulder the task of low-carbon personnel training and become an important force to cultivate low-carbon talent. However, with the advent of the era of low-carbon economy, the community put forward new and higher demands on talent, and talent market competition is more intense.

In order to adapt to the talent market competition in the era of low-carbon economy, colleges and universities must adjust the professional structure, innovate the training mode[1] to cultivate the new talents who can be accepted by the low-carbon economy market, and have very strong adaptability and self-regulation ability. And In order to achieve this goal, it is necessary to build a training platform with characteristics and competitiveness to cope with the opportunities and challenges of the low-carbon economy.

Based on the analysis of the talent market prospect and the talent cultivation strategy in the transition period to the low-carbon economy, this paper aims at the exploration and establishment of a unique specialty training goal and its support system of knowledge and ability requirements for energy majors. The results obtained have a reference to the cultivation of composite low-carbon talents who have both low-carbon ideas and knowledge structure. 


\section{Opportunities and Challenges of Talent Cultivation in Transition to Low-carbon Economy}

Energy is an important foundation for human survival and development. For a long time, the energy used in the world is still dominated by fossil fuels. Fossil fuels are non-renewable energy, no doubt, will be less and less with the consumption, at the same time, fossil fuel combustion will produce serious environmental pollution.

With the accelerated development of social economy and the constant increase of energy consumption, the shortage of energy and the caused environmental pollution is more and more serious, which directly threatens economic development and human survival[2].

In order to effectively deal with these problems, the transformation to a low-carbon economic development model has become the trend of world economic development. The low-carbon economy [3] [4] will also included into the overall development strategy in our country, to realize the national economic and social sustainable development [3][4].

The low-carbon economy is a new industrial revolution characterized by low-carbon energy [5]. Every industrial revolution in mankind is a historic challenge and opportunity. The challenge we are facing now is that we has not yet come out of the pattern of traditional society and face the requirement of accelerating modernization. The key is whether we can seize this opportunity and be able to lay down coping strategies, policies and measures to deal with the challenges. The key to seize the opportunity and to deal with challenges are talents. Therefore, for low-carbon economy and talent strategy, we should start from the talent strategy.

The practice of the international community shows that the realization of low-carbon development requires innovation in policies, technologies and ideas, and the innovation requires talents, especially high-level talents, low-carbon economic competition is essentially the competition of talents [6].

To solve the problem of shortage of talent in the development of low-carbon economy has attracted the attention of the relevant parties. It is of strategic significance to carry out low-carbon education for the students in colleges and universities, and it is an effective guarantee for national energy and economic sustainable development.

This situation is both opportunities and challenges for energy professionals in the talent training.

Why to say it is an opportunity is because the economic transformation requires a large number of low-carbon talents, making the low-carbon talents lack, for the students to open up a broad employment space. Why to say it is a challenge is because of the diversification of talent required by the low-carbon economy and the increase in employment requirements, as well as the lag and imbalance in economic transformation and development. These are adverse factors to employment.

Due to the restriction of economic development speed, the transition to low-carbon economy can not be achieved overnight, which will result in the imbalance between the development of higher education and social demand, and the imbalance will exist for a long time. Employment conflicts are more prominent and exist for a long time. Especially there is a great gap between the personnel training with low-carbon thinking and low-carbon knowledge structure, and the personnel quality requirements. There is a great gap and a contradiction between the social needs and the college personnel training, as shown in Table 1.

Table 1 The characteristics of social needs and the characteristics of talent cultivation in Colleges and universities

\begin{tabular}{|l|l|}
\hline The characteristics of social needs & the characteristics of talent cultivation in colleges and universities \\
\hline $\begin{array}{l}\text { The diversity and rapidity of low-carbon } \\
\text { social demand }\end{array}$ & $\begin{array}{l}\text { The relative stability and lagging of talent cultivation in colleges } \\
\text { and universities }\end{array}$ \\
\hline $\begin{array}{l}\text { The particularity of low - carbon society 's } \\
\text { demand for talents }\end{array}$ & The universality of cultivating talents in colleges and universities \\
\hline $\begin{array}{l}\text { Universality and crossover of employment } \\
\text { subjects }\end{array}$ & The specialization of talent cultivation in colleges and universities \\
\hline
\end{tabular}


To solve these contradictions, the key is to market-oriented to train talents. The quality and characteristics of personnel training are the key factors to measure the competitiveness of higher education. Without their own characteristics and advantages, it is difficult to have a foothold in the competitiveness of many colleges and universities in the talent training. Especially today in the advent of low-carbon economy is even more so

\section{Characteristic Objectives and Requirements of Low-carbon Talents Training}

For the talents training of energy majors, the determination and accurate positioning [7] of talent training goal are very important. On this basis, through the establishment of the corresponding characteristic curriculum system to achieve the training objectives [8], we can seize the opportunities brought about by low-carbon economy, deal with the challenges faced by low-carbon personnel training, so as to improve the competitiveness of personnel training.

The professional training platform with a distinctive feature is the fundamental guarantee to achieve the training goal of energy professionals. This professional training platform should have the characteristics [9][10] shown in Table 2.

Table 2 Characteristics of training platform for professional training

\begin{tabular}{|l|l|}
\hline characteristics & function \\
\hline With a wide range of professional caliber & Increasing students' ability to adapt \\
\hline With distinctive features & Enhance the competitiveness of personnel training \\
\hline With low-carbon concept and knowledge structure & Meet the talent needs of low-carbon economy \\
\hline
\end{tabular}

Wide professional caliber should be treated differently, according to the accurate position which can reflect school's own characteristics and advantages.

For high-level key universities, the professional caliber of personnel training can be wider. Their cultivation of wide professional caliber in the undergraduate can not only lay a good foundation for students to enter the graduate stage, but also open up a wider employment channel for students because of the advantages of the school reputation.

For the relatively low level of general colleges and universities, the caliber of its personnel training should broaden to a smaller scope. In the appropriate expansion of professional caliber, professional counterparts should be considered mainly, the education in application professional knowledge should be strengthened, so that graduates get employed quickly.

Therefore, the establishment of the curriculum system must conform the school's positioning and personnel training objectives, can meet the requirements of low-carbon talent training and conform school characteristics. It has distinctive features and is operational. Only in this way we can make the quality and effect of talent training be improved, and then, the competitiveness of professional personnel training be enhanced.

The curriculum system in our school's energy majors is based on the above considerations to build.

According to the social needs of low-carbon personnel and the characteristics of energy majors to cultivate low-carbon personnel, in other to effectively deal with opportunities and challenges of low-carbon economy, according to the school's own characteristics, we established distinctive and effective professional training objectives. It is the primary task and the necessary conditions for the talent training of energy majors. In view of this, we established the professional training objectives of energy and power engineering shown in Table 3.

Graduates must meet the requirements shown in table 4 . These requirements are the necessary support to realize training target. 
Table 3 Professional training objectives and include areas of energy and power engineering

\begin{tabular}{|l|l|l|}
\hline $\begin{array}{l}\text { goal } \\
\text { term }\end{array}$ & professional training goals & \multicolumn{1}{c|}{ include areas } \\
\hline I & $\begin{array}{l}\text { Strengthen the basic } \\
\text { knowledge, pay attention to } \\
\text { practical application }\end{array}$ & $\begin{array}{l}\text { To strengthen the basic knowledge of the natural sciences such as } \\
\text { mathematics, mechanics, thermodynamics, and computer application, etc; } \\
\text { to strengthen the training to solve practical application problems; to adapt to } \\
\text { different technical positions and social development needs. }\end{array}$ \\
\hline II & $\begin{array}{l}\text { Pay attention to professional } \\
\text { skills and strengthen } \\
\text { engineering capacity }\end{array}$ & $\begin{array}{l}\text { To pay attention to learning the professional knowledge, to accept the } \\
\text { systematic engineering practice and professional skills training, to train } \\
\text { innovation awareness and team spirit; to familiar with the use of } \\
\text { professional tools and scientific literature,to adapt to social development } \\
\text { needs for various technical innovation talents. }\end{array}$ \\
\hline III & $\begin{array}{l}\text { Obtain cultural literacy, } \\
\text { create a sound personality }\end{array}$ & $\begin{array}{l}\text { To pay attention to learning humanities, social science, to enhance cultural } \\
\text { literacy, create a sound personality and social responsibility, training a } \\
\text { certain international vision and cross-cultural communication skills, to } \\
\text { adapt different technical positions and social development needs. }\end{array}$ \\
\hline
\end{tabular}

Table 4 The decomposition of the graduation requirements and the support of the training objectives

\begin{tabular}{|l|l|}
\hline goal requirements & $\begin{array}{l}\text { support } \\
\text { term }\end{array}$ \\
\hline $\begin{array}{l}\text { With solid mathematics and other natural science, as well as technical knowledge in the field of energy } \\
\text { and power engineering, with the ability to solve engineering problems }\end{array}$ & I \\
\hline $\begin{array}{l}\text { Ability to apply the basic principles of math, physics, chemistry, mechanics and professional expertise to } \\
\text { identify, express, use literature and analyze engineering issues and get effective conclusions }\end{array}$ & I \\
\hline $\begin{array}{l}\text { Ability to use scientific principles and scientific methods to research the engineering problems for boiler, } \\
\text { refrigeration and air conditioning equipment and other thermal technology equipment and their systems }\end{array}$ & II \\
\hline $\begin{array}{l}\text { Be able to work out solutions to engineering problems in this majors, to design that meet the needs, be } \\
\text { able to use professional standards and specifications, and demonstrate innovative awareness }\end{array}$ & II \\
\hline $\begin{array}{l}\text { Able to develop, select and use professional engineering tools and resources for energy and power } \\
\text { engineering issues, }\end{array}$ & II \\
\hline $\begin{array}{l}\text { Master the necessary professional knowledge in a professional direction, with strong engineering } \\
\text { application ability, preliminary understanding of the forefront of science and development trends }\end{array}$ & II \\
\hline $\begin{array}{l}\text { With a certain literacy of humanities and social science, strong sense of social responsibility and } \\
\text { engineering ethics, good language and interpersonal communication skills }\end{array}$ & III \\
\hline $\begin{array}{l}\text { Master at least one foreign language, be able to read the professional foreign language information, have } \\
\text { a certain international perspective and cross-cultural communication skills }\end{array}$ & III \\
\hline $\begin{array}{l}\text { With a certain basic knowledge and ability in management and technical and economic aspects, strong } \\
\text { team spirit and team work ability }\end{array}$ & III \\
\hline With a lifelong education awareness, with the ability of independent learning and continue to learn & I,II,III \\
\hline
\end{tabular}

\section{Summary}

The low-carbon economy is a global revolution related to the production mode, life style and values, is the only way to realize the sustainable development of China's economy. For the demand cultivating problems of low-carbon talents, there are two aspects: one the talent shortage in this field, another is the talent requirements improved and diversified, to make our talent supply and demand imbalance. In addition, low-carbon economy may also lead to a considerable number of industries shut down and caused structural unemployment. So that, for colleges and universities, the opportunities and challenges coexist.

In the background of the popularization of education and low-carbon economy, if higher education, especially General higher schools and universities, want to keep a foothold in the competition of talent training, they must establish and perfect a talent training platform which has distinctive features, its own advantages and adapt to low-carbon talent training requirements. Among them, the orientation of the universities and colleges is essential. 
The research and exploration on low-carbon talent training objectives which have a distinctive feature are able to meet the requirements of low-carbon talents, for the accurate construction of personnel training platform have an important leading role, which will help improve the competitiveness of professional personnel training. It will influence the survival and development of higher school.

Of course, the training platform under the new training objectives run more difficult, still needs a lot of research work to do. Our energy professionals in this area have done some useful attempts and exploration. We believe that with the deepening of higher education reform and the establishment of scientific operational mechanism, the perfect and featured personnel training platform will be able to play a huge role for the realization of low-carbon talent training in the competition of higher education.

\section{Acknowledgements}

This work was supported by Heilongjiang Association of Higher Education (HGJXH B1110521). To express gratitude to them, at one time, to give thanks to other colleagues of our Department of Energy and Power Engineering who give us help.

\section{References}

[1] X.N. Chen: Cooperative Economy and Science Technology, (2014) No 16, p.173.

[2] J. Liang, H. Yin, J. X. Guo, F. Liao: Collected Ppapers of Forum on Second China Energy Scientist (Xuzhou, China, 2010),(2010), p891.

[3] H. J. Zhao: Enterprise Research, (2011) No 14, p14.

[4] Y. Gu: Shopping Mall Modernization, (2013) No 18, p192.

[5] P.G. Clem, M. Rodriguez, J.A. Voigt and C.S. Ashley, U.S. Patent 6,231,666. (2001)

[6] H. T. Zhu: Chinese College Students Employment, (2011 ) No 1, p45.

[7] Y.M. Huo: Education and Occupation, (2012) No6, p30.

[8] F. D. Zhang: Higher Agricultural Education, (1013) No 8, p29.

[9] S. G. Luo: Chinese University Teaching, (2013) No 5, p15.

[10] S. G. Luo: Road to Success, (2016) No 35, p25. 